Đorđe Kaličanin $^{1}$
Saša Veljković $^{2}$
Zoran Bogetić $^{3}$
JEL: M31, L25, G32

DOI: 10.5937/industrija43-7592

UDC: 005.345:005.936.43

$005.42 \quad 658.14 / .17$

Original Scientific Paper

\title{
Brand orientation and financial performance nexus
}

\author{
Article history: \\ Received: 21 January 2015 \\ Sent for revision: 4 February 2015 \\ Received in revised form: 2 March 2015 \\ Accepted: 8 March 2015 \\ Available online: 1 April 2015
}

\begin{abstract}
The aim of the article was to find nexus between brand orientation and financial performance in companies doing business in Serbia. We surveyed general managers, marketing managers, and brand managers in order to examine their views on the brand orientation dimensions of their companies. We matched the survey results with financial performance of those companies (EBITDA margin) in order to find linkages between these variables. We got expected results in the sense that strong brand orientation and weaker brand barriers lead to better financial performance. Overall brand orientation is significantly positively correlated with EBITDA margin, and brand barriers are significantly negatively correlated with that measure. We analysed the brand orientation and brand barriers between groups of companies classified according to their size, internationalization, origin of company ownership, origin of brand, specific business area of key brands and type of goods sold. Interestingly, there are undoubted differences in brand orientation and brand barriers only between foreign and domestic companies. These differences could be seen as one of the main reasons of differences between their EBITDA margins. Also, we saw some differences in brand orientation in case of companies with international brands in relation to companies with domestic brands, but those differences are fewer and smaller. We did not find any other statistically significant difference. The significance of the paper is in emphasizing that development of brand orientation of domestic companies could lead to improvement of their profitability and competitiveness.
\end{abstract}

\footnotetext{
${ }^{1}$ University of Belgrade, Faculty of Economics, Belgrade, kalicanin@ekof.bg.ac.rs

2 University of Belgrade, Faculty of Economics, Belgrade

${ }^{3}$ University of Belgrade, Faculty of Economics, Belgrade 
Keywords: brand orientation, brand barriers, brand management practice, financial performance, ownership structure.

\section{Veza između orijentacije ka brendu i finansijskih performansi}

Apstrakt: Cilj članka je bio da pronađemo vezu između orijentacije ka brendu i finansijskih performansi u preduzećima koja posluju u Srbiji. Anketirali smo generalne menadžere, marketing menadžere $i$ brend menadžere u cilju ispitivanja njihovih pogleda na dimenzije orijentacije ka brendu u njihovim preduzećima. Rezultate ove ankete doveli smo u vezu sa finansijskim performansama ovih kompanija (marža EBITDA) u cilju pronalaženja veze između tih promenljivih. Dobili smo očekivane rezultate u smislu da jaka orijentacija ka brendu i slabije barijere brendu dovode do boljih finansijskih performansi. Ukupna orijentacija ka brendu je značajno pozitivno korelisana sa ovim merilom, a barijere brendu su značajno negativno korelisane sa istim merilom. Analizirali smo orijentaciju ka brendu i barijere brendu između grupa preduzeća klasifikovanih prema veličini, internacionalizaciji, poreklu vlasništva nad preduzećem, poreklu brenda, specifičnog poslovnog područja ključnih brendova $i$ vrste robe koja je predmet poslovanja. Zanimljivo, nesumnjive razlike u orijentaciji ka brendu i barijerama brendu postoje samo prilikom poređenja stranih i domaćih preduzeća. Ove razlike se mogu shvatiti kao jedan od glavnih razloga razlika u njihovim EBITDA maržama. Takođe, uvideli smo neke razlike u orijentaciji ka brendu i barijerama brendu u slučaju preduzeća koja rade sa internacionalnim brendovima u odnosu na preduzeća koja rade sa domaćim brendovima, ali je ovih razlika u manjem broju, a i po veličini su manje. Nismo pronašli nikakve druge statistički značajne razlike. Značaj ovog rada ogleda se u naglašavanju da unapređenje orijentacije ka brendu domaćih preduzeća može da vodi unapređenju njihove profitabilnosti $i$ konkurentnosti.

Ključne reči: orijentacija ka brendu, barijere brendu, praksa brend menadžmenta, finansijske performanse, struktura vlasništva.

\section{Introduction}

Nowadays, brand is seen as one of the most important intangible assets with a very strong influence on market value of companies. That is the reason why brand is a special subject of management - brand management (BM) and why brand management practice (BMP) has become a focus of many practitioners and researchers. 
Because of its importance, it is obvious that brand should not be the exclusive domain of marketing management. It should be the central point of connection and communication between many departments and management levels, and an integral part of the main processes. This way of thinking has led to a new phenomenon - brand orientation. Brand oriented companies see brand as a core competence and the foundation of business development. In those companies, brand links internal and external stakeholders aiming at value creation.

Brand orientation is a complex phenomenon. It can be understood as consisting of several dimensions, like: innovativeness, brand commitment, brand monitoring, strategy permeation, elimination of brand barriers, etc.

A mirror of all business activities is financial performance (the other side of the coin of business activities). That means that we need to observe brand orientation through the perspective of creating shareholder (owners') value.

The focus of this paper is to investigate the nexus between brand orientation dimensions (BODs) and financial performance of companies in Serbia. Although, there was the empirical investigation about brand orientation in nonprofit sector in Serbia (e.g. Mandarić, Sekulić, \& Pantić, 2012), our paper aims to fill the lack of research on the relationship between BODs and financial performance in for-profit organizations in our country, as well as to compare the results of our study with the results of similar studies conducted in other countries. The paper will first present the theoretical background and literature review on this nexus, then, we will focus on the presentation of the research methodology and, finally, we will discuss our findings.

\section{Theoretical background and literature review}

Intangible assets have the greatest impact on the creation of enterprise market value today. The most valuable intangible assets relate to customer relations, employee skills and their knowledge, information technology and organizational culture fruitful for innovation, problem solving and general improvement of the organization. Brand and brand equity have a special place in that category of assets. Brand equity is a multidimensional concept composed of brand strength and brand value. Brand strength relates to consumer effects associated with brands, and brand value relates to the financial valuation of the brand. From managerial standpoint, one of the primary tasks for managers is to maximise brand equity in order to increase brand value (Raggio \& Leone, 2009). Besides, brands are important intangible assets that significantly contribute to firm performance, while brand equity is measured in the most convenient way by revenue premium (Ailawadi, Lehmann, \& Neslin, 2003; Huang \& Sarigöllü, 2014). On the other hand, 
company performance as dependent variable of brand strength can be measured by sales, EBITDA or market share (Herrmann, Henneberg, \& Landwehr, 2010).

Brand is one of the main sources of competitive advantage (Djuričin, Janošević, \& Kaličanin, 2013, p. 89), even in industrial economy when we had a kind of product standardization on brand platform (Djuričin et al., 2013, p.236). Economic profit is a proof of that advantage. Putting a value on a brand as a source of competitive advantage is important in several ways, because of: internal communications, brand positioning and communication, brand value tracking and management, external growth (Haxthausen, 2009).

Importance of intangible assets is much more obvious in the case of service organizations rather than the producing ones. But today, service industries predominate in most national economies. It follows that intangible assets is a key creator of value for consumers, and consequently for business owners. Djordjević \& Veljković (2012) explore how the importance of brands (brand significance) in the value chain can be used as a basis for segmentation of tourist market.

However, Ambler, Bhattacharaya, Edell, Keller, Lemon, \& Mittal (2002) point out that the spread of pure service-based industries has led to the development of the customer equity concept. Customer equity is the present value of the future cash flows from customers buying all brands. On the other hand, brand equity relates to future cash flows from the sales of that brand. Besides, improvements in customer equity and brand equity are significantly related to firm value (Srinivasan \& Hanssens, 2009). It is the same case with improvements in consumer appraisal in terms of perceived quality, particularly for new products, then with product innovation and innovativeness, with the opening of new distribution channels, and not the case with price promotions (negatively related to firm value).

In addition, the impact on the financial performance of the brand is not the same everywhere. For instance, brands play a more important role in the success of food and beverage companies than of the B2B technology companies (whose intangible assets consist of knowledge and technologies) (Knowles, 2003). Mizik (2014) showed that impact of brand asset on profitability is direct and contemporaneous in restaurant sector, while in the high-tech sector brand impact is realized in future with significant delay, and in distribution/retail sector there are positive current and positive future impacts of brand asset on profitability.

The most of literature often focuses on world's famous successful brands of large organizations. BMP in small and medium enterprises (SMEs) is overlooked by researchers. However, there are differences between SMEs and large organizations in the extent to which they implement key BMPs. 
More interestingly, BMPs in high-performing SMEs and low-performing SMEs is different. The differences relate to respecting the "branding basics": understanding customers' needs and brand perceptions, creating relevant and valued brands, supporting the brand consistently over time, effectively communicating the brand's identity to internal and external stakeholders and creating coherent brand architecture (Berthon, Ewing, \& Napoli, 2008).

The place of intangible assets (and therefore brand) in the strategic logic of value creation for the owners can most easily be seen in the strategy map (Kaplan \& Norton, 2000, 2004). The strategy map is a logical and comprehensive architecture for the description of one strategy. It describes the critical elements of strategy (strategic initiatives) and their interconnections.

The core of any business unit strategy is the value proposition that is delivered to the consumer. The proposition describes the value of a unique mix of products, prices, services, relationships and the image which the provider offers to the consumer. Brand has an irreplaceable position in that proposition. The company differentiates its value proposition, choosing one of three strategies: operational excellence, customer intimacy and product leadership (Treacy \& Wiersema, 1995).

Strategy map is basis for the creation of a Balanced Scorecard (BSC). BSC as a comprehensive framework contains goals, their measures, quantitative targets and initiatives or actions for their achievement (Kaplan \& Norton, 1996, 2001). It enables efficient strategy implementation, business planning and makes a basis for compensation system building. In addition, it is compatible with new the approach to cost accounting as Activity Based Costing - ABC (Kaličanin \& Knežević, 2013). As BSC has become a widely accepted strategic management technique, many organisations have incorporated their brands and brand strategy into their scorecards. One of the first things to do is to develop a kind of brand strength scorecard, which can include, for instance, several measures: market share, market share trend, average contract value, price elasticity of demand, share of wallet, customer satisfaction, customer loyalty, cost per lead, conversion rate, brand differentiation. Such a measurement system that links brand investment to business performance enables organizations to manage brands in a way that increases firm value (Munoz \& Kumar, 2004).

In the modern business strategy, brand represents the focus of communication between the ones who are brand visionaries, brand providers and brand believers. The excellence in the value delivery and a strong brand experience is achieved when there is strong internal alignment with the brand among internal stakeholders and resources and strong alignment among external stakeholders, partners and customers (Srivastava \& Thomas, 2010, p.466). 
Nowadays, brand is seen as a resource and a strategic hub of the company, and the goal of brand oriented approach is to satisfy the needs and wants of the consumer, within the limits of the brand core identity (Urde, Baumgarth, \& Merilles, 2013). In brand orientated organizations we can find usual statements as: branding flows through all our marketing activities, branding is essential to our strategy, branding is essential in running this company, longterm brand planning is critical to our future success, the brand is an important asset for us, everyone in this firm understands that branding our product/service is a top priority of our business (Wong \& Merrilees, 2007).

Brand comes alive through people, systems and processes. For this reason, the strategic approach and building brand are essential, not only externally, but also within the company (Veljković, 2010, p.161).

There are successful attempts for brand orientation index (BOI) construction which shows overall brand orientation of an organization. Moreover, Gromark and Melin showed that 15 per cent of the operating margin (EBITA) can be explained by the level of BOI (Gromark \& Melin, 2011).

Although we have noted that the value of the company mainly derives from the value of intangible assets, and therefore from the brand value, brand valuation in recent years has been developed as a separate discipline and sound methodology. At least four factors have enabled the development of brand valuation methods: measuring marketing performance, justifying share prices, trading brands and tax management (Salinas \& Ambler, 2009). Today, the brand valuation industry is quite developed with several dozen players, and Interbrand is a pioneer in this industry. Although there are several models of evaluation, it is possible to distinguish three general approaches to evaluation: cost (which predicts the costs of brand development), market (in terms of recording prices at which similar brands are traded in a sufficient number of transactions) and income (based on the projection of cash flows generated by the brand).

Regardless of the method used to estimate the value of the brand, it is clear that the valuation of the brand should not be a purpose in itself. Increasing the value of the brand should enable the improvement of the financial performance of a company. In this regard, it is necessary to investigate the relationship between brand value and performance of a company because, like other investments, investments in building brand value should lead to maximizing shareholder value. In addition, such a connection facilitates testing market viability of investment in the brand. Finally, such a proven link leads to the inclusion of brand equity in the balance sheet (Yeung \& Ramasamy, 2008). This leads to a new view of marketing spending. Because of the significant relationship between relative market share and cash flow performance (levels and variability), in contrast to accounting standards and 
conventions, marketing spending should be treated as an investment rather than an expense (Morgan \& Rego, 2009).

Uncovering the link between branding and financial performance has attracted the attention of the business and scientific community in recent years. Singh, Faircloth, \& Nejadmalayeri (2005) suggest significant positive relationship between advertising expenditure and market value added (MVA). Conchar, Crask, \& Zinkhan prove that there is a positive relationship between enterprise spending on advertising and promotion, and its market value, which supports the notion of a connection between the brand-building activities and financial performance of the company. It is expected that these investments will lead to maximizing cash flows in the future and, consequently, increasing the shareholders' wealth (Conchar et al, 2005). This cash flow can be generated only by changes in consumer behaviour engendered by the ability of companies to leverage the equity of their brands (Das, Stenger, \& Ellis, 2009). Marketing expenditure should increase firm value, and marketing's efforts should make revenues (and cash flow) first (Hanssens, Rust, \& Srivastava, 2009).

Madden, Fehle, \& Fournier (2006) emphasize the role of brand in reducing the volatility and vulnerability of cash flows, as well as conceptualization of brand as a powerful risk management tool. Strong brands have less risk of failure than weak brands. Because of that they require less risk premium (Hupp \& Powaga, 2004). Customer satisfaction could be seen as a strategic buffer against uncertainty in turbulent times. That is the reason why investors use customer satisfaction as a proxy for the ability of a company to generate future cash flows (Kambara, 2010). Besides, customer satisfaction is positively related to capital market reputation, and capital market reputation is positively related to firm performance (accounting returns and shareholder value).

Strong brands can increase cash flow in four ways: obtaining higher prices (premium prices), higher volume growth, lower costs (economies of scale in marketing and distribution), higher asset utilisation (because of integration with suppliers and distributors reductions in inventories, manufacturing and distribution assets). Brands also can increase business value by: accelerating cash flows, increasing the continuing value of cash flow and reducing the cost of capital (Doyle, 2000, pp. 229-232). Shareholder value is higher when strong brands are extended into territories, than weaker ones (Sjödin, 2007). Besides, Booz Allen Hamilton and Wolff Olins European survey among Marketing and Sales Officers showed that brand-guided companies producing industrial goods achieved an EBITDA of $17 \%$ against $10 \%$ for remaining companies (Harter, et al. 2005). They also found in case study banks that brand-guided companies surveyed achieved a return on equity of $19 \%$ against $8 \%$ for remaining companies. 
Financial measure influences market valuations only to the extent that it drives investor expectations about future performance. Nowadays, companies are in a position to use a great number of financial measures: traditional (predominantly accounting) and modern (value-based) measures and integral approach to their choice is considered as appropriate (Kaličanin, 2005). But, financial performance measures explain only 40-60 per cent of the variations in market values; in highly branded sectors, individual measures of brand health correlate 30-60 per cent with variations in market value; both financial measures and brand health measures explain up to 80 per cent of the variance in valuations in some sectors (Knowles, 2003).

Although brand is the subject of attention both in companies that apply differentiation strategy, as well as in the companies that implement cost leadership strategy, research has shown that the importance of brands for value creation in financial terms (not in the sense of customer value) is higher in the case of differentiation strategies. Indeed, differentiation is the driver of margin: the higher a brand's differentiation, the higher its current margin and future potential. One can rarely gain in volume what it sacrifices in margin. Brands that sacrifice share to maintain margin deliver significant levels of incremental EVA; and increasing market penetration while losing differentiation results in relatively minor value creation (Knowles, 2003). Moreover, differences in business value are related to differences in profit margins and firms with higher margins should have higher value-to-sale multiples (Mizik \& Jacobson, 2009).

\section{Overview of research methodology}

The research was conducted by collecting responses to the survey with CEOs, marketing managers and brand managers of 74 companies in the Republic of Serbia, for the period 1/06/2014 to $1 / 07 / 2014$. The response rate was 17 percent.

We used a web-based questionnaire in which managers had to provide answers to all the questions. Although managers were asked about the name of their companies, we emphasized that those data would not be publicized. Further, we divided questionnaire into two parts. The first part contained questions about characteristics of the company, and the second part contained questions about attitudes of managers on brand orientation dimensions. Attitudes were examined using a seven-point Likert Scale. We asked the respondents to be honest in their answers and not to give socially desirable answers.

As a measure for the size of the company we used official categorization of the companies found on the website of the Serbian Business Registers 
Agency. All the companies were grouped into small and medium enterprises (SM) and large enterprises (L). Companies were also divided in two categories regarding their internationalization (if they generated any sales abroad or not) as internationalized (I) or non-internationalized (N-I). According to their origin of company ownership we divided all the companies into foreign (FC) and domestic ones (DC). Besides, according to the origin of brand, we divided all the companies into two groups: with international brands (IB) and with domestic brands (DB). The last two categorizations were according to the type of goods sold. Specific business area of key brands was selected by the managers within a list containing the following industries: fresh and frozen food, packaged food, non-alcoholic beverages, alcoholic drinks, non-food FMCG, pharmaceutical and related products, durable goods and small appliances, and others. All these industries were agglomerated into two big categories: producers $(P)$ and distributers/foreign representations offices (DR). Further, companies were divided into two broad groups: first group of businesses of fast-moving consumer goods or consumer packaged goods (FMCG) and second group of other businesses which mostly sell durable goods, here named as other business-to-consumer companies (Other B-toC).

The summary of the number of companies in each group (subsamples) is provided in Table 1.

Table 1. Sample characteristics

\begin{tabular}{|c|c|c|c|c|c|c|c|c|c|c|c|c|}
\hline \multicolumn{13}{|c|}{ No of companies } \\
\hline \multirow{2}{*}{ All } & \multicolumn{2}{|c|}{ Size } & \multicolumn{2}{|c|}{$\begin{array}{l}\text { International- } \\
\text { ization }\end{array}$} & \multicolumn{2}{|c|}{$\begin{array}{l}\text { Origin of } \\
\text { company }\end{array}$} & \multicolumn{2}{|c|}{$\begin{array}{l}\text { Origin of } \\
\text { brand }\end{array}$} & \multicolumn{2}{|c|}{$\begin{array}{l}\text { Business } \\
\text { area }\end{array}$} & \multicolumn{2}{|c|}{ Type of goods } \\
\hline & $\mathrm{L}$ & SM & $\mathrm{N}-\mathrm{I}$ & I & FC & DC & IB & DB & $\mathrm{P}$ & DR & $\begin{array}{c}\text { FMC } \\
\text { G }\end{array}$ & $\begin{array}{c}\text { OTHE } \\
\text { R } \\
\text { B-to-C }\end{array}$ \\
\hline 74 & 32 & 42 & 13 & 61 & 25 & 49 & 29 & 45 & 52 & 22 & 55 & 19 \\
\hline
\end{tabular}

Source: Authors' calculations

The subject of our research was to establish the relationship between the dimensions of brand orientation (BODs) and financial performance of the company. Financial performance of the analyzed companies could not be tracked through measures from the financial markets in Serbia because this market is undeveloped with few investment alternatives, a modest level of trading on them and a small number of investors. So we were forced to focus on the accounting performance measure. EBITDA margin was used as a proxy for financial performance.

Financial performance of companies that is (or should be) influenced by BODs is EBITDA margin. EBITDA margin should indicate past profits which is often a good indicator of the firm's future ability to be profitable and generate 
positive cash flows. Obviously, EBITDA margin is not influenced only by brand orientation and brand barriers, but by other factors in production, research and development, supply chain or finance, for instance. Nevertheless, our assumption was inspired by Gromark and Melin (2011) when they found a relationship between brand orientation (with some different dimensions in relation to ours) and operating margin (EBITA), as well as by survey conducted by Booz Allen Hamilton and Wolff Olins (Harter, et al. 2005).

Our additional analyses were focused on finding differences between BODs in different companies grouped according to the previously described characteristics. We observed BODs through the perception of the surveyed managers in terms of overall brand orientation, which should have a positive impact on financial performance.

As key dimensions of brand orientation in our model we pointed out: Innovativeness, Brand commitment, Brand monitoring, and Marketing channel relationships.

Innovativeness reflects the orientation of the company to new ideas and solving business problems in a creative way, here we included it in BODs because it has close ties with marketing and brand activities in the company. Of course, it is in the domain of responsibility of the marketing department, as well as of other departments, for instance, R\&D.

Brand commitment means true orientation of the organization and its managers to brand and brand management. This is evident through various organizational processes, attitudes towards investment and strategic approach to branding, etc.

Legislation related to accounting, does not require a separate recording and bookkeeping information about brands. On the other hand, it is impossible to manage brands without information about their income and expenses. It is also necessary to know their market share, track perceptions of brands, the effectiveness of investing in brands, etc. Therefore, it is necessary to monitor and control the outcomes of brands.

Distributors and retailers enable companies to connect brands with the market and consumers. Developing good relationships in marketing channels is a prerequisite for successful brand positioning. Manufacturers, distributors, and retailers are partners, not enemies. On the one hand, a reputable brand is a connection between partners, and on the other hand, a good relationship between the parties, affects the successful introduction of new brands. This is particularly important in the B-to-C segment.

Finally, we made the assumption that there are certain barriers that hinder a company in its brand orientation and thus affect the financial performance but in a negative way. These are brand barriers specific to the organization itself 
or its systems, processes, culture, and attitudes of its managers and employees regarding the perception of the brand as a key intangible asset.

Furthermore, in our study we formulated the items that describe the brand orientation and brand barriers. So, we asked managers to evaluate their practices in their firms according to the items described in table 2.

Table 2. Description of factors and items and Cronbach' alpha

\begin{tabular}{|c|c|c|c|}
\hline $\begin{array}{l}\text { Factors of } \\
\text { influence }\end{array}$ & $\begin{array}{l}\text { Latent variable } \\
\text { (Brand } \\
\text { orientation } \\
\text { dimensions) }\end{array}$ & Description of single items & $\begin{array}{l}\text { Cronbach's } \\
\text { alpha }\end{array}$ \\
\hline \multirow[t]{4}{*}{$\begin{array}{l}\text { Brand } \\
\text { orientation } \\
\text { (positive } \\
\text { influence on } \\
\text { financial } \\
\text { performance) }\end{array}$} & $\begin{array}{l}1 . \\
\text { Innovativeness }\end{array}$ & $\begin{array}{l}5 \text { items regarding: quality of } \\
\text { technology innovation system, } \\
\text { new ideas consideration, } \\
\text { implementation of new } \\
\text { technologies, active research for } \\
\text { new ideas, rate of innovations } \\
\text { relate to competition }\end{array}$ & .819 \\
\hline & $\begin{array}{l}\text { 2. Brand } \\
\text { commitment }\end{array}$ & $\begin{array}{l}6 \text { items regarding: brand } \\
\text { importance, long range planning in } \\
\text { BM, branding flows through all } \\
\text { marketing activities, role of brands } \\
\text { in business strategy, employee } \\
\text { education regarding BM }\end{array}$ & .708 \\
\hline & $\begin{array}{l}\text { 3. Brand } \\
\text { monitoring }\end{array}$ & $\begin{array}{l}5 \text { items regarding: monitoring } \\
\text { market effects, perception } \\
\text { measures, financial indicators, } \\
\text { branding costs }\end{array}$ & .804 \\
\hline & $\begin{array}{l}\text { 4. Marketing } \\
\text { channel } \\
\text { relationships }\end{array}$ & $\begin{array}{l}4 \text { items regarding: information } \\
\text { about brands toward } \\
\text { retailers/distributors and back to } \\
\text { us, retailers' ability to present } \\
\text { brand to end-users, brand } \\
\text { reputation in B2B relationships }\end{array}$ & .690 \\
\hline \multicolumn{2}{|c|}{$\begin{array}{l}\text { Brand barriers } \\
\text { (negative influence on financial } \\
\text { performance) }\end{array}$} & $\begin{array}{l}6 \text { items regarding: not recording } \\
\text { brand costs, brand building is } \\
\text { understood in organization as cost } \\
\text { not as an investment, lacking } \\
\text { brand investments, } \\
\text { branding is seen as "exclusive } \\
\text { practice" of large companies, and } \\
\text { "very expensive activity", while the } \\
\text { lowest prices is the key factor in } \\
\text { brand positioning }\end{array}$ & .721 \\
\hline
\end{tabular}

Source: Authors' calculations 
For each answer, a separate seven-point Likert Scale (Strongly disagree, Disagree, Disagree somewhat, Undecided, Agree somewhat, Agree, Strongly Agree) was given.

Cronbach's Alpha is the most commonly used indicator to measure internal consistency and therefore reliability of a questionnaire. The values for Cronbach's Alpha were all above the acceptable limit of 0.7, except for one latent variable, which was slightly below 0.7 (Marketing channel relationships, 0.69). Therefore, Cronbach's alpha has proven that all included items in particular factors of BODs can be used as one single measurement.

Identifying the relationship between BODs and financial performance implied the analysis in several fields:

- identifying linkages between BODs and EBITDA margin;

- analysis of companies with above average EBITDA margin, and companies with below average EBITDA margin, and identifying the factors influencing that financial measure;

- examination of the differences in BODs between the groups of companies grouped according to the following characteristics: size, internationalization, origin of the company, origin of the brand, business area, type of goods.

We took the data on EBITDA margin from the business portal of CUBE Risk Management Solutions, the company that provides business information and credit risk services (www.cube.rs). We used the statistical program IBM SPSS v20 to perform the statistical analysis.

\section{Research results and discussions}

In the analysis we used test of Pearson's Correlation. The test showed that EBITDA margin is significantly positively correlated with brand orientation and significantly negatively correlated with brand barriers at the level of 0.01 (Table 3). We can conclude that general brand orientation, and brand barriers directly affect the EBITDA margin, but in different directions.

Average EBITDA margin of the whole sample was $8.41 \%$ and Median was $7.75 \%$. Median was used to set a line to divide the whole sample into two groups: first group of companies with above average EBITDA margin, and the second group of companies with below average EBITDA margin. It turned out that we had exactly 37 companies in each of such established groups. 
Kaličanin $Đ$. et al.: Brand orientation and financial performance nexus

Table 3. Correlations between EBITDA margin and brand orientation and brand barriers

\begin{tabular}{|c|c|c|c|}
\hline \multicolumn{2}{|c|}{} & $\begin{array}{c}\text { BRAND ORIENTATION } \\
- \text { ALL4 }\end{array}$ & BRAND BARRIERS \\
\hline \multirow{3}{*}{$\begin{array}{c}\text { EBITDA } \\
\text { MARGIN }\end{array}$} & $\begin{array}{c}\text { Pearson } \\
\text { Correlation }\end{array}$ & $.307^{* *}$ & $-.323^{* *}$ \\
\cline { 2 - 4 } & Sig. (2-tailed) & .008 & .005 \\
\cline { 2 - 4 } & $\mathrm{N}$ & 74 & 74 \\
\hline \multirow{2}{*}{$* *$ significant at the 0.01 level. }
\end{tabular}

Source: Authors' calculations

Next, we investigated the influence of certain factors - dimensions of brand orientation and brand barriers on EBITDA margin. The survey results showed that there are differences in the mean per individual factors between the two groups of companies (Figure 1). We run t-tests to compare the means of the two sample groups. Statistically significant differences existed in the factors: innovativeness, brand monitoring, and brand barriers (significant at the 0.01 level), and brand management commitment (significant at the 0.05 level). Also, a statistically significant difference was found for the brand orientation observed as a result of all these dimensions (at the 0.01 level).

Figure 1. BODs comparison of two groups of companies with different EBITDA margins

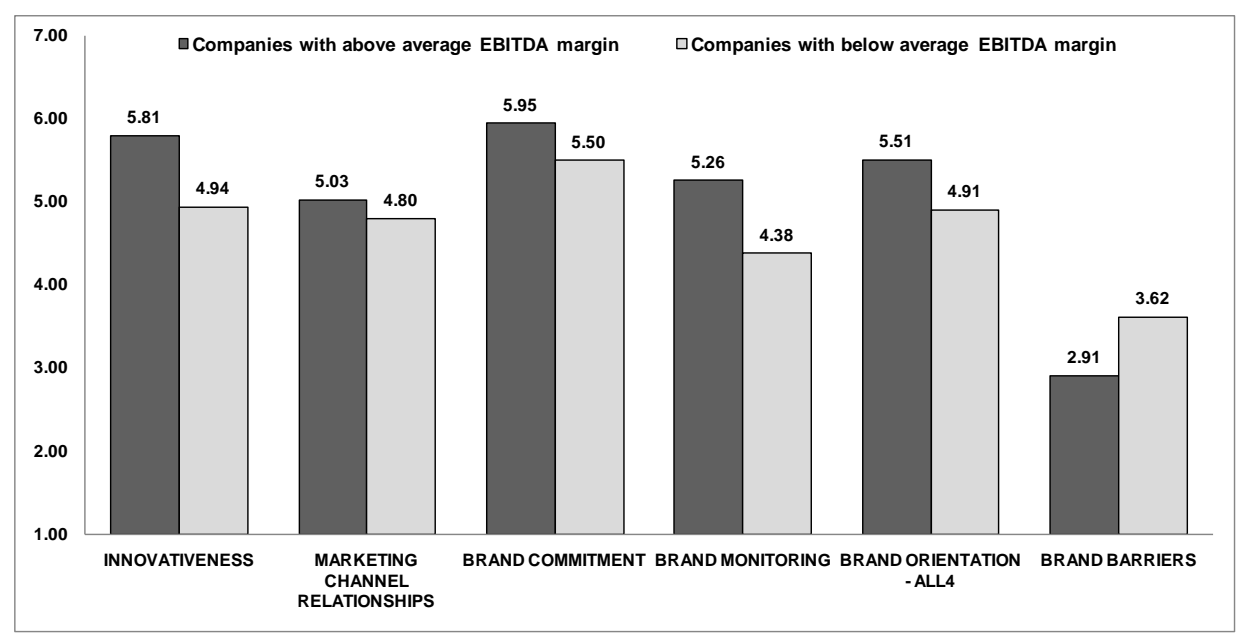

Source: Authors' calculations 
Furthermore, we ran t-tests to compare two sample means of the groups of companies with different business profiles to determine if there was any statistically significant difference between their BODs and between their EBITDA margins. EBITDA margin for each group from sample is shown in Table 4.

Table 4. EBITDA margin (\%) in different categories

\begin{tabular}{|c|c|c|c|c|c|c|c|c|c|c|c|c|}
\hline \multirow{2}{*}{ All } & \multicolumn{2}{|c|}{ Size } & \multicolumn{2}{|c|}{$\begin{array}{c}\text { Internationalizati } \\
\text { on } \\
\end{array}$} & \multicolumn{2}{|c|}{$\begin{array}{l}\text { Origin of } \\
\text { company }\end{array}$} & \multicolumn{2}{|c|}{$\begin{array}{c}\text { Origin of } \\
\text { brand }\end{array}$} & \multicolumn{2}{|c|}{$\begin{array}{c}\text { Business } \\
\text { area }\end{array}$} & \multicolumn{2}{|c|}{ Type of goods } \\
\hline & $\mathrm{L}$ & SM & $\mathrm{N}-\mathrm{I}$ & I & $\mathrm{FC}$ & DC & IB & DB & $P$ & DR & $\begin{array}{c}\text { FMC } \\
\text { G }\end{array}$ & $\begin{array}{c}\text { OTHE } \\
\text { R } \\
\text { B-to-C }\end{array}$ \\
\hline 8.41 & $\begin{array}{c}6.9 \\
0\end{array}$ & $\begin{array}{c}9.5 \\
6\end{array}$ & 5.02 & 9.13 & 12.64 & $6.25^{\star \star}$ & 9.10 & 7.96 & 8.27 & 9.71 & 7.46 & 11.15 \\
\hline
\end{tabular}

Source: Authors' calculations

T-test showed that there was a statistically significant difference in EBITDA margin only in the case of origin of the company at the 0.01 level. This suggests that there was a significant difference in brand management practices conducted in the two groups of companies. Foreign-owned companies achieved significantly higher EBITDA margin due to stronger brand orientation and weaker brand barriers. Although there were differences in the EBITDA margin in other groups, these differences were not statistically significant.

Table 5. The levels of particular elements of BODs

\begin{tabular}{|c|c|c|c|c|c|c|c|c|c|c|c|c|c|}
\hline \multirow{3}{*}{ Factors } & \multicolumn{13}{|c|}{ Mean } \\
\hline & \multirow{2}{*}{ All } & \multicolumn{2}{|c|}{ Size } & \multicolumn{2}{|c|}{$\begin{array}{c}\text { Internationaliza } \\
\text { tion }\end{array}$} & \multicolumn{2}{|c|}{$\begin{array}{l}\text { Origin of } \\
\text { company }\end{array}$} & \multicolumn{2}{|c|}{$\begin{array}{c}\text { Origin of } \\
\text { brand }\end{array}$} & \multicolumn{2}{|c|}{$\begin{array}{c}\text { Business } \\
\text { area }\end{array}$} & \multicolumn{2}{|c|}{ Type of goods } \\
\hline & & L & SM & $\mathrm{N}-\mathrm{I}$ & I & FC & DR & IB & DB & $P$ & DR & $\begin{array}{c}\text { FMC } \\
\text { G }\end{array}$ & $\begin{array}{c}\text { OTH } \\
\text { ER } \\
\text { BtoC }\end{array}$ \\
\hline $\begin{array}{l}\text { Innovativen } \\
\text { ess }\end{array}$ & $\begin{array}{c}5.37 \\
3 \\
\end{array}$ & $\begin{array}{c}5.08 \\
1 \\
\end{array}$ & $\begin{array}{c}5.59 \\
5 \\
\end{array}$ & 5.631 & 5.318 & $\begin{array}{c}5.70 \\
4 \\
\end{array}$ & 5.204 & $\begin{array}{c}5.67 \\
6 \\
\end{array}$ & $\begin{array}{c}5.17 \\
8\end{array}$ & $\begin{array}{c}5.24 \\
6 \\
\end{array}$ & $\begin{array}{c}5.62 \\
1 \\
\end{array}$ & $\begin{array}{c}5.36 \\
0 \\
\end{array}$ & 5.411 \\
\hline $\begin{array}{l}\text { BM } \\
\text { commitmen } \\
\text { t }\end{array}$ & $\begin{array}{c}5.72 \\
3\end{array}$ & $\begin{array}{c}5.73 \\
4\end{array}$ & $\begin{array}{c}5.71 \\
5\end{array}$ & 5.602 & 5.749 & $\begin{array}{c}5.94 \\
6\end{array}$ & 5.609 & $\begin{array}{c}5.85 \\
6\end{array}$ & $\begin{array}{c}5.63 \\
7\end{array}$ & $\begin{array}{c}5.71 \\
8\end{array}$ & $\begin{array}{c}5.73 \\
6\end{array}$ & $\begin{array}{c}5.76 \\
6\end{array}$ & 5.597 \\
\hline $\begin{array}{l}\text { Brand } \\
\text { monitoring }\end{array}$ & $\begin{array}{c}4.82 \\
2\end{array}$ & $\begin{array}{c}4.53 \\
8\end{array}$ & $\begin{array}{c}5.03 \\
8\end{array}$ & 4.738 & 4.839 & $\begin{array}{c}5.41 \\
6\end{array}$ & $\underset{\star \star}{4.518}$ & $\begin{array}{c}5.10 \\
3\end{array}$ & $\begin{array}{c}4.64 \\
0\end{array}$ & $\begin{array}{c}4.76 \\
2\end{array}$ & $\begin{array}{c}4.96 \\
8\end{array}$ & $\begin{array}{c}4.90 \\
9\end{array}$ & 4.568 \\
\hline $\begin{array}{l}\text { Marketing } \\
\text { channel } \\
\text { relationship }\end{array}$ & $\begin{array}{c}4.91 \\
2\end{array}$ & $\begin{array}{c}4.83 \\
6\end{array}$ & $\begin{array}{c}4.97 \\
0\end{array}$ & 4.923 & 4.910 & $\begin{array}{c}5.26 \\
0\end{array}$ & $\begin{array}{c}4.735 \\
*\end{array}$ & $\begin{array}{c}5.25 \\
9\end{array}$ & $\begin{array}{c}4.68 \\
9^{*}\end{array}$ & $\begin{array}{c}4.81 \\
3\end{array}$ & $\begin{array}{c}5.15 \\
8\end{array}$ & $\begin{array}{c}4.83 \\
2\end{array}$ & 5.145 \\
\hline $\begin{array}{l}\text { Brand } \\
\text { orientation } \\
\text { ALL 4 }\end{array}$ & $\begin{array}{c}5.20 \\
8\end{array}$ & $\begin{array}{c}5.04 \\
9\end{array}$ & $\begin{array}{c}5.33 \\
0\end{array}$ & 5.224 & 5.205 & $\begin{array}{c}5.58 \\
2\end{array}$ & $\underset{\star \star}{5.018}$ & $\begin{array}{c}5.47 \\
5\end{array}$ & $\begin{array}{c}5.03 \\
6^{*}\end{array}$ & $\begin{array}{c}5.13 \\
5\end{array}$ & $\begin{array}{c}5.37 \\
2\end{array}$ & $\begin{array}{c}5.21 \\
8\end{array}$ & 5.181 \\
\hline $\begin{array}{l}\text { Brand } \\
\text { barriers }\end{array}$ & $\begin{array}{c}3.26 \\
1\end{array}$ & $\begin{array}{c}3.19 \\
8 \\
\end{array}$ & $\begin{array}{c}3.30 \\
9 \\
\end{array}$ & 3.240 & 3.360 & $\begin{array}{c}2.58 \\
7 \\
\end{array}$ & $\begin{array}{c}3.606 \\
\star \star \\
\end{array}$ & $\begin{array}{c}3.06 \\
9 \\
\end{array}$ & $\begin{array}{c}3.85 \\
1 \\
\end{array}$ & $\begin{array}{c}3.28 \\
5 \\
\end{array}$ & $\begin{array}{c}3.24 \\
6 \\
\end{array}$ & $\begin{array}{c}3.25 \\
8 \\
\end{array}$ & 3.271 \\
\hline
\end{tabular}

* significant at the 0.05 level, ** significant at the 0.01 level.

Source: Authors' calculations 
Our finding about strong relationship between brand orientation and financial performance is in line with the findings of Gromark \& Melin (2011), Conchar et al. (2005), Harter et al. (2005) as well as with Ailawadi et al. (2001).

Next, we wanted to determine the reasons for any difference in EBITDA margin between foreign and domestic companies. This prompted us to research the differences between BODs within these sub-samples. We recorded the following estimates of dimensions, as shown in Table 5.

In the case of company origin, except the difference in the EBITDA margin, there were statistically significant differences in:

- brand monitoring,

- marketing channel relationship,

- overall brand orientation, as well as in

- brand barriers.

Although we did not find statistically significant difference between the EBITDA margin for the other groups, it is interesting to point out that there were differences in practices between the companies classified by origin of brand (statistically significant difference in overall brand orientation, and marketing channel relationship - at the 0.05 level). This can be interpreted as a consequence of transferring (or perhaps the imposition) of BMPs from companies that own international brands (or their principals) to domestic companies (distributors, manufacturers on the basis of a license agreement, etc.).

\section{Conclusion}

We embarked on the research aware of some limitations and circumstances. The conditions of undeveloped financial markets in Serbia that clearly send signals about the effectiveness of business decisions (including decisions on branding), forcing us to relate the practice (especially state of BODs) with short-term performance criteria, such as EBITDA margin. We avoided taking into account the measures of value creation, for instance, Total Shareholder Return (TSR) or Market Value Added (MVA). Nevertheless, it could be useful to make correlation tests with other financial measures, for instance with Return on assets (ROA), or maybe Economic Value Added (EVA).

Besides, despite the considerable number of international companies surveyed, this study has been conducted in one country only, the Republic of Serbia. We think that interesting results could be obtained by similar studies across the region and the EU. 
We are aware of the limitation that the answers of the surveyed managers regarding the company brand orientation could reflect their personal views of brand orientation, not the general perception at the level of the whole organization. Perhaps, a kind of group answers of relevant "brand carriers" in a surveyed company could give us better insight in BODs in that company.

This survey was conducted in the period of global economic and financial crisis, when margins, ROA and ROE were on the lower level, and when all companies from different industries were not affected to the same extent. It could be very interesting to conduct longitudinal studies to see if the BODs would lead to better, sustainable profitability in the period after the world economic crisis. Finally, note that we analyzed only companies from B-to-C sector.

However, despite those limitations and circumstances, it is possible to point out several important conclusions:

- brand orientation could be analysed considering the following dimensions: innovativeness, brand commitment, brand monitoring, and marketing channel relationships. They are items of good BMP. Brand barriers are identified as items of bad BMP;

- there is a clear nexus between brand orientation, brand barriers and financial performance (EBITDA margin) of the surveyed companies;

- brand orientation is positively correlated, and brand barriers negatively correlated with financial performance (EBITDA margin);

- companies with above average EBITDA margin and companies with below average EBITDA margin differ significantly in: innovativeness, brand commitment, brand monitoring, and brand barriers;

- foreign companies implement efficient brand management practice that make companies brand oriented, that in final instance, leads to better financial performance;

- companies which deal with international brands have stronger brand orientation in relation to the companies which deal with domestic brands.

These conclusions lead us toward specific recommendation for managers of local companies. It relates primarily to the execution of benchmarking of foreign companies regarding their BODs. This will include an in-depth analysis of each element in all dimensions of brand orientation in the sense of the description of its condition and identification of precise directions for its improvement. The purpose of this process is improvement of the innovation processes, enhancement of management in marketing channel relationships, creation of a brand performance measurement system and development of brand commitment. 
These conclusions give us the right to believe that the final result of this process could be enhancement of competitiveness and profitability of local companies, and raising the competitiveness of the national economy. In this sense, this study has social significance.

\section{References}

Ailawadi, K.L., Lehmann, D.R., \& Neslin, S.A. (2003). Revenue premium as an outcome measure of brand equity. Journal of Marketing, 67 (October), 1-17.

Ambler, T., Bhattacharaya, C.B., Edell, J., Keller, K.L., Lemon, K.N., \& Mittal, V. (2002). Relating brand and customer perspective on marketing investment. Journal of Service Research, 5 (1), 13-25.

Berthon, P. Ewing, M., \& Napoli, J. (2008). Brand management in small to mediumsized enterprises. Journal of Small Business Management, 46 (1), 27-45.

Conchar, M.P., Melvin, R.C., Zinkhan, G.M. (2005). Market valuation models of the effect of advertising and promotional spending: A review and meta-analysis. Journal of the Academy of Marketing Science, 33 (4), 445-460.

Das, S., Stenger, C., \& Ellis, C. (2009). Managing tomorrow's brands: Moving from measurement towards an integrated system of brand equity. Journal of Brand Management, 17 (1), 26-38.

Djordjević, A., \& Veljković, S. (2012). Segmentation of tourist market based on brand significance in the value chain. The Role of Contemporary Management and Marketing Methods in Improvement of Competitiveness of the Companies in Serbia within the Process of its Integration to the European Union I editor Nebojša Janićijević, University of Belgrade, Faculty of Economics, Belgrade, 351-383.

Doyle, P. (2000). Value-Based Marketing: Marketing Strategies for Corporate Growth and Shareholder Value, John Wiley \& Sons, Ltd. Chichester.

Djuričin, D., Janošević, S., \& Kaličanin, Dj. (2013). Menadžment i strategija. Ekonomski fakultet, Beograd.

Gromark, J., \& Melin. F. (2011). The underlying dimensions of brand orientation and its impact on financial performance. Journal of Brand Management, 18 (6), 394410.

Hanssens, D.M., Rust, R.T., \& Srivastava R.K. (2009). Marketing strategy and Wall Street: Nailing down marketing's impact. Journal of Marketing, 73 (November), 115-118.

Harter, G., Koster, A., Peterson, M., \& Stomberg, M. (2005). Managing Brands for Value Creation. Retrieved on 26/03/2015 from http://www.boozallen.com/media/file/Managing_Brands_for_Value_Creation.pdf

Haxthausen, O. (2009). Valuing brands and brand investments: Key learnings and future expectations. Journal of Brand Management, 17 (1), 18-25.

Herrmann, A., Henneberg, S., \& Landwehr, J. (2010). Squaring customer demands, brand strength, and production requirements: A case example of an integrated product and branding strategy. Total Quality Management, 21 (10), 1017-1031.

Huang, R., \& Sarigöllü, E. (2014). Assessment of brand equity measures. International Journal of Market Research, 56 (6), 783-806. 
Hupp, O., \& Powaga, K. (2004). Using consumer attitudes to value brands: Evaluation of the financial value of brands. Journal of Advertising Research, (September), 225-231.

Kaličanin, Dj. (2005). Merenje performansi zasnovano na vrednosti, Ekonomika preduzeća, Year LIII, No. 3-4, 91-100.

Kaličanin, Dj., \& Knežević, V. (2013). Activity-based costing as an information basis for an efficient strategic management process. Economic Annals, Year LVIII, No. 197, 95-119.

Kambara, K.M. (2010). Managing brand instability and capital market reputation: Implications for brand governance and marketing strategy. Journal of Brand Management, 17 (8), 568-578.

Kaplan R.S., \& Norton D.P. (2000). Having Trouble with Your Strategy? Then Map It! Harvard Business Review. (September-October), 167-176.

Kaplan R.S., \& Norton D.P. (2001). The Strategy-Focused Organization: How Balanced Scorecard Companies Thrive in the New Business Environment. Harvard Business School Press, Boston, Massachusetts.

Kaplan, R.S., \& Norton, D.P. (1996). The Balanced scorecard: Translating Strategy into Action. Harvard Business Press.

Kaplan, R.S., \& Norton, D.P. (2004). Strategy Maps: Converting Intangible Assets into Tangible Outcomes. Harvard Business Press.

Knowles, J. (2003). Value-based brand measurement and management. Interactive Marketing, 5 (July/September), 40-50.

Madden, T., Fehle, F. \& Fournier, S. (2006). Brands matter: An empirical demonstration of the creation of shareholder value through branding. Journal of the Academy of Marketing Science, 34 (2), 224-235.

Mandarić, M., Sekulić, D., \& Pantić, N. (2012). Empirical Investigation of brand orientation in the non-profit sector. Conference Proceedings of $2^{\text {nd }}$ International Scientific Conference "Contemporary Issues in Economics, Business and Management - EMB 2012", Edited by Babić, V., Faculty of Economics, University of Kragujevac, Kragujevac, 2013, 227- 237.

Mizik, N. (2014). Assessing the total financial performance impact of brand equity with limited time-series data. Journal of Marketing Research, 51 (6), 691-706.

Mizik, N., \& Jacobson, R. (2009). Valuing branded businesses. Journal of Marketing, 73 (November), 137-153.

Morgan, N.A., \& Rego, L.L. (2009). Brand portfolio and firm performance. Journal of Marketing, 73 (January), 59-74.

Munoz, T., \& Kumar, S. (2004). Brand metrics: Gauging and linking brands with business performance. Journal of Brand Management, 11 (5), 381-387.

Raggio, R.D., \& Leone, R.P. (2009). Chasing brand value: Fully leveraging brand equity to maximize brand value. Journal of Brand Management, 16 (4), 248-263.

Salinas, G., \& Ambler, T. (2009). A taxonomy of brand valuation practice: Methodologies and purposes. Journal of Brand Management, 17 (1), 39-61.

Singh, M., Faircloth, S., \& Nejadmalayeri, A. (2005). Capital market impact of product marketing strategy: evidence from the relationship between advertising expenses and cost of capital. Journal of the Academy of Marketing Science, 33 (4), 432-444.

Sjödin, H. (2007). Financial assessment of brand extensions. Journal of Brand Management, 14 (3), 223-231. 
Kaličanin $Đ$. et al.: Brand orientation and financial performance nexus

Srinivasan, S., \& Hanssens, D. (2009). Marketing and firm value: Metrics, methods, findings, and future directions. Journal of Marketing Research, 46 (June), 293312.

Srivastava, R.K., \& Thomas, G.M. (2010). Managing brand performance: Aligning positioning, execution and experience (editorial). Journal of Brand Management, 17 (7), 465-471.

Treacy, M., \& Wiersema F. (1995). The Discipline of Market Leaders: Choose Your Customers, Narrow Your Focus, Dominate Your Market (Reading, MA: AddisonWiley) according to Kaplan, R., \& Norton, D. (2001). The Strategy-Focused Organization: How Balanced Scorecard Companies Thrive in the New Business Environment, Harvard Business School Press, Boston, Massachusetts, 86-87.

Urde, M., Baumgarth, C., \& Merriles, B. (2013). Brand orientation and market orientation - from alternatives to synergy. Journal of Business Research, 66, 1320.

Veljković, S. (2010). Brend menadžment u savremenim tržišnim uslovima. Ekonomski fakultet, Beograd.

Wong, H.Y., \& Merrilees, B. (2007). Closing the marketing strategy to performance gap: the role of brand orientation. Journal of Strategic Marketing, 15 (December), 387-402.

Yeung, M., \& Ramasamy, B. (2008). Brand value and firm performance nexus: Further empirical evidence. Journal of Brand Management, 15 (5), 322-335. 